\title{
GIS IN TOURISM DEVELOPMENT USING SPATIAL MODELLING
}

\author{
Vytautè JUODKIENË ${ }^{1, *}$
}

${ }^{1}$ Geodesy Department, Technology and Landscape Management Faculty, Kaunas University of Applied Sciences, Pramonès pr. 20, LT-50468 Kaunas.

corresponding author: vytautejuodkiene@yahoo.com.

\section{Abstract}

The article deals with a spatial problem - setting the best places for tourism development in Panevėžys district (Lithuania). In order to select areas using ArcGIS software, there was developed a model that evaluated the criteria that influence the selection of areas suitable for tourism. The article presents a digital map, which indicates most suitable locations for rural development by evaluating zones by points in order of importance. The evaluation scale is from 10 points (the most suitable location) to 2 points (the least suitable location). Evaluation points in thematic maps indicate exact locations that are most suitable for tourism homesteads.
\end{abstract}

\author{
Keywords: \\ Tourism development; \\ Spatial modelling; \\ Geoinformation database; \\ Euclidean Distance; \\ GIS technology.
}

\section{Introduction}

In the developed countries, the provision of services is the most important economic activity and the service sector is one of the most advanced and expanding economic spheres [1]. Under the influence of social and political globalization processes, the provision of tourism services becomes the dominant economic sector in many countries. Tourism is one of the most effective branches of the economy successfully competing with oil and gas extraction. The dynamism that characterizes its development and which does not exist in other branch of the economy, has led according to the data of the World's Tourism Organization (WTO) to the creation of about $130 \mathrm{mln}$. jobs, it makes 15 pct. of foreign trade balance, 10.9 pct. of Gross Domestic Product, its share of gross investment is $7-8$ pct. Economic processes taking place in Lithuania, the development of international relations with other countries of the world lead to the development of international tourism. Most attractive for tourism development until 2020, in the opinion of the experts, should be seven Lithuanian municipalities which generate highest tourist flows and have the highest tourist potential - three major cities Vilnius, Kaunas, Klaipeda and four resorts Birštonas, Druskininkai, Neringa, and Palanga. It is suggested to direct investments according to their demand, economic yield and investment return, i.e. to invest into the destinations with the highest flows of tourists. The priority directions should remain the same until 2020 (cultural, business (conferences), health and active leisure tourism). It is also recommended to add a new direction - city breaks, which is rapidly becoming popular in the largest Lithuanian towns and resorts due to the development of budget flights and can be very viable. The analysis of the expert opinions on the most viable inbound tourism markets and the effectiveness of tourism marketing measures until 2020 shows that it is recommended to promote tourist flows from four target groups - from the neighbouring countries (Russia, Belarus, Latvia, Poland, Germany), from Scandinavian countries, with a special focus on business tourism, from potential or growing tourism markets (Ukraine, Israel) where marketing should be strengthened in order to be able to expect tourist flows in the future, and from the long-haul markets - the U.S., Canada, China, Japan. The future of tourism marketing is in e-marketing, communication, social networks and mobile applications, however, in the Eastern Markets (Russia, Belarus, Ukraine) the main tourism marketing means should remain traditional, such as printed matter, participation in tourism fairs or business missions because tourists in these countries do not use the internet so often when planning their travels compared to tourists from Western countries [3]. The objectives of tourism development in the general structure of Lithuanian economy have an influence on and are closely linked with strategies of other branches of the economy, as well as with factors and instruments provided for therein. The effective development of tourism is possible only having a balanced organizational structure at all levels and strong 
coordination relations. In case of demand, the creation of new homesteads becomes relevant. Of course, it is important to choose the right place for such homestead. GIS technologies may serve for this purpose, and then solution of the problem will become simple. GIS technology is becoming more and more important in people's everyday life. A wide range of organizations use GIS technology. These technologies and software help to deal with questions of different complexity, which other information system technologies are unable to overcome. The advantage of GIS is that it collects data about the spatial objects, provides analysis, modeling and relationships between them. From a technical point of view, this is expressed by the possibility to orient geographically different objects and data. The exceptional advantage would be spatial analysis and data processing at various levels.

The objective of this study is to identify areas suitable for tourism development in Panevėžys district using GIS technologies, i. e. spatial modelling. The object of the study is tourism business development in Panevėžys district.

\section{Material and methods}

There are several methods of data processing in ArcGIS environment. The choice of method depends on the complexity of the task and the user qualification. The process of data processing, which uses a set of tools, is automated using models. The model consists of one or, more often several processes that are associated with each other. You can add new or remove unnecessary processes at any time, i. e. in a changeable situation the models can be easily edited.

In order to use the possibilities of spatial modeling for determination of certain areas, it is necessary to form some steps: identification of the problem; splitting of the problem into separate issues; study of the importance of different issues; types of modeling; follow-up; the final result. The article uses data of Lithuanian geoinformation database GDB200 and creates a model using software ArcGIS 10.1, which uses Euclidean Distance, Reclassify and Weighted Overlay tools. According to the Euclidean distance formula, the distance between two points in the plane with coordinates $(x, y)$ and $(a, b)$ is given by:

$\operatorname{dist}[(x, y),(a, b)]=\sqrt{ }(x-a)^{2}+(y-b)^{2}$.

The empirical study is based on the following scientific research methods:

- theoretical and systematic analysis of scientific literature was applied for the analysis of the main theoretical statements of tourism governance and the new public governance in order to create a tourism governance model revealing the essential tourism governance factors and their interaction as well as synergy;

- comparative analysis was used to analyze and compare theoretical tourism governance statement and to explore the good practice in place in the governance of tourism issues in other countries;

- documentary analysis was applied for the study of the concepts of tourism governance models, laws, strategic planning documents, reports of international organisations, official statistics in order to identify the principles and functions of tour-ism governance as well as assess the practical level of regulation;

- internet websites assessment was reviewed in order to make an estimation and compare the capacity level of Lithuanian municipalities to create opportunities for tourism online;

- GIS (Geographic Information System) modelling can take on various forms; the typical method preferred in a land use context is that of resource/environmental modelling which takes many environmental factors such as slope, hydrology, etc. and combines them into a ranked model. For a successful GIS model there must be a clear inventory of the features to be modeled and the factors that the model will use, such as roads, lakes, forests, slopes, and other natural characteristics. As well, the creator should research and determine what program will be used to create the model (eg. ArcGIS is Model Builder), and if any type of programming language (eg. Avenue programming) will be used to automate the model creation process. In terms of GIS modelling, the data methods or sources are usually raster or vector, line and polygon data. It is usually preferable to use vector data structure when modeling in GIS. These methods are general environmental methods and not necessarily specific to tourism modelling. 


\section{Results and discussion}

Tourism service sector in Panevėžys district has a sufficiently great potential for growth, however its development yet is limited by the fact that the supply and quality of tourism services still lags behind international standards. Therefore, for a successful tourism sector development, it is necessary to improve the image of Panevėžys district as a tourism region and regularly use marketing tools, adapt cultural heritage objects and natural resources for tourism purposes, develop tourism infrastructure and increase supply of tourism services in terms of quantity. Taking into account the current tourism situation in the municipality of Panevėžys, the following suggestions may be provided:

- To stimulate establishment of new tourism service companies;

- To stimulate the occurrence of new tourism services;

- To increase the number of tourists and the duration of their sojourn in the municipality;

- More actively form a positive image of the region;

- To encourage closer communication between local tourism institutions and business representatives;

- $\quad$ To build an attractive image of rural tourism.

The main rural tourism development resources can be distinguished: the natural environment, suitable for leisure (the picturesque landscape, forests, waters and other natural resources), cultural heritage suitable for recreational needs (towns having cultural heritage, villages, areas with valuable individual objects and living culture events). In order to select the most appropriate areas, it is necessary to create a so-called suitability model to evaluate a number of criteria that determine rural tourism homestead visitors flow, profit, quality of services provided and other criteria that determine the successful creation of rural tourism homestead.

Taking into account these needs, the stated objective was divided into separate issues in accordance with specific criteria. Knowing and understanding the objective, we divide the formulated issues into ever smaller ones until they can be measured and their relevance or importance can be evaluated.

The first criteria (one of the most important) - is the distance between the trunk road and other roads. The road would be asphalted or covered with a hard ground surface. Of course, the homestead should not be located too close to the trunk road as visitors and tourists come to the homestead in order to get away from engine noise and polluted air. The closer area is located to the road, i. e. from 0 to $1000 \mathrm{~m}$, the lower the point -2 - is given to this area. This is because the high traffic volume causes high levels of noise. In addition, areas located in the vicinity of the roads are more polluted by exhaust emissions. Therefore, when looking for a suitable location for tourism development, we must pay a special attention to this criterion. The highest point -10 - is for those areas that are located from the roads at a distance of $1000-3000 \mathrm{~m}$. These areas are the most suitable for tourism development. The areas located at a greater distance from the roads, from 5000 to $6000 \mathrm{~m}$, were given 8 points, because these areas are characterized by lower noise levels and less pollution. It is not recommended to choose places for homesteads located very far from the road, i. e. $11000 \mathrm{~m}$ and more. Large distances entail inconveniences on tourists to find homesteads. Therefore, these areas were evaluated by 4 points (Fig. 1).

All other criteria (places to visit, tourist attractions) affecting the availability of tourism homesteads were similarly divided. The distance to the lakes, rivers, resorts, forests was taken into account. Forests have also been assessed using a ten-point scale for assessing the suitability. The maximum assessment point was 10 , i. e. $0-2000 \mathrm{~m}$. area. If the forest is near the homestead, it creates a greater amount of services provided to the tourists and has an impact to the greater profit of a homestead. The minimum amount of points -2 was given to the areas located far away from the forests, i. e. from 9000 to $11000 \mathrm{~m}$.

Also there was assessed the area of influence of the existing homesteads, which is very important because a new homestead should be built away from the existing homesteads. The smaller the distance to the existing homestead the greater competition, and, of course it is more difficult to attract more tourists. The greater the distance the competition decreases and this would bring more profit to the homestead. Therefore, areas located from 13000 to $16000 \mathrm{~m}$, were appraised by the highest point -10 . As already mentioned, too small distance to the existing tourism areas is not good, therefore the distance from 0 to $3000 \mathrm{~m}$ were appraised by only 2 points (the worst place) (Fig. 2). 


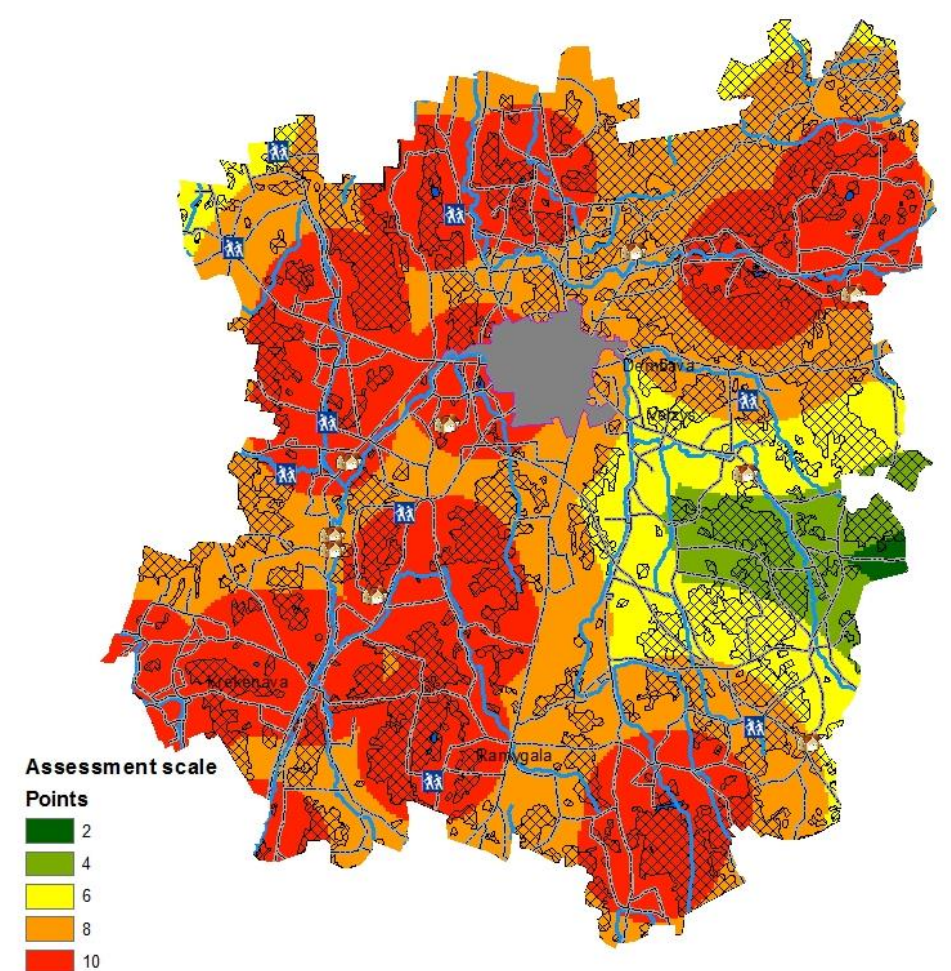

Fig. 1: The scheme of a number of areas of influence.

As it is impossible to observe all phenomena of our surrounded environment at the same time, therefore we use new models, which artificially create reality. The division of GIS data into separate layers, their coordination provides great opportunities for modeling. Modeling is a tool and a way of analyzing spatial problem when direct measurements and observations are not possible. The euclidean distance (spatial analyst) afford us to calculate for each cell, the euclidean distance to the closest source, the input source data can be a feature class or raster. In our case, because the input source was a raster, the set of source cells consisted of all cells in the source raster that have valid values. The reclassify (spatial analyst) is a tool that promotes the reclassification or change of the values in a raster. and used in the reclassify tool process the following inputs (roads euclidean distance, lakes euclidean distance and places to visit euclidean distance,etc), in a total of 5 reclassification. In order to obtain the final result, i. e. a digital map with determination of the most appropriate locations for tourism development, it is necessary to evaluate all areas by points according to the relevance and create their thematic maps. The assessment scale is from 10 points (the most suitable location) to 2 points (the least suitable location). Evaluation points in thematic maps indicate exact locations that are most suitable for tourism homesteads.

The last stage of the model - bring together all areas of influence of availability (areas of influence of places to visit, areas of influence of roads, areas of influence of rivers, areas of influence of lakes, areas of influence of forests, areas of influence of rural tourism homesteads) and distinguish areas suitable for rural tourism development in Panevėžys district. This was done using Spatial Analyst module function Weighted Overlay (Fig. 3).

Having summed up all points of the most suitable areas we got a digital map (Fig. 4) with identified areas for rural tourism development.

Those places, where areas according to the assessment scale have been assessed in 10 points, are the most suitable (red color). The areas assessed in 8 points do not have all the required criteria that affect the profitable rural tourism business development. Areas marked with green color the worst place - are those areas in which it is possible to develop tourism, but these areas are affected by one or the other above mentioned factors and will be less visited. As is obvious, there are not many areas suitable for tourism development in Panevėžys district. There have been selected the suitable areas for tourism development in accordance with all the criteria for attractiveness. 


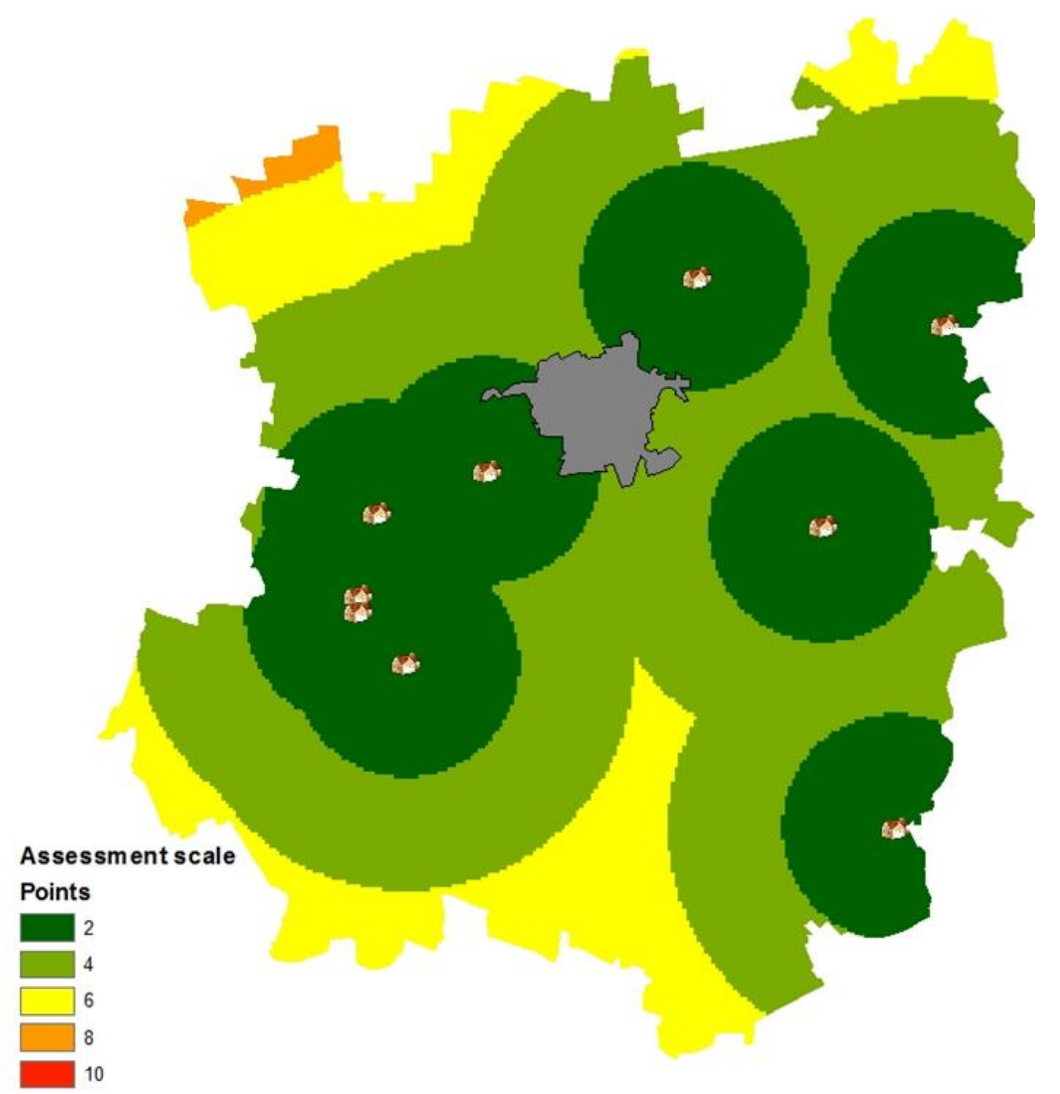

Fig. 2: Areas of influence of the existing tourism homesteads.

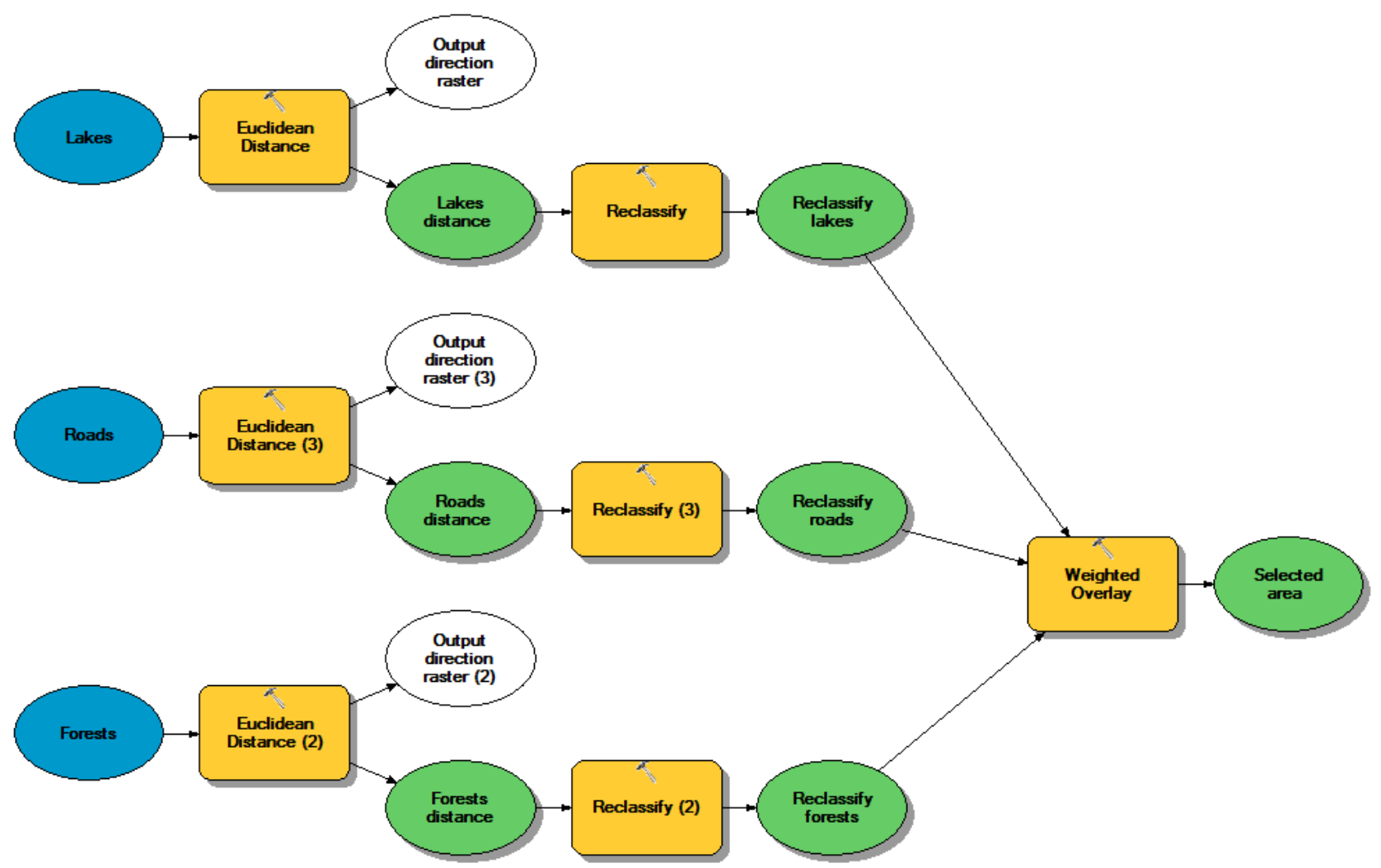

Fig. 3: Fragment of a created model. 


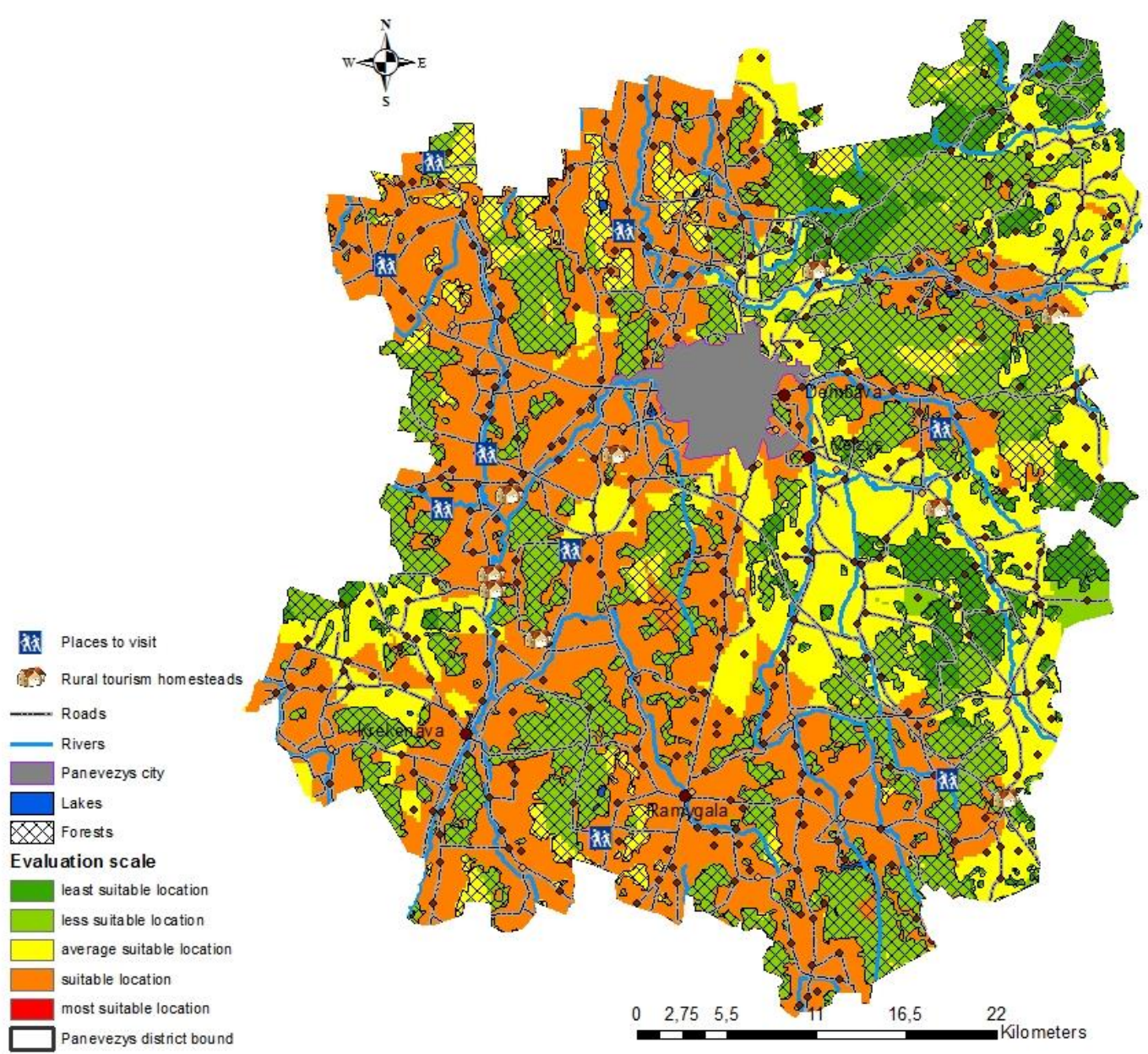

Fig. 4: Areas suitable for rural tourism in Panevėžys district.

\section{Conclusions}

The spatial problem was solved by using GDB200 and creating corresponding layers of Panevéžys district: forests, rural tourism homesteads, lakes and rivers, roads and places to visit.

For selection of areas, there was developed a model which was used to determine Panevėžys district tourism development. The possibility to repeat the application of model for solving the same task with other parameter values gives the advantage for spatial modeling.

In the area of consideration, there wasn't selected area assessed in 10 points according to suitability for rural tourism homesteads. More suitable areas were assessed in 8 points. This is because this region of Lithuania is not rich in lakes; therefore the tourism sector is not widely developed.

The most popular places to visit - Krekenava Regional Park, Burbiškis and Puziniškis manors, narrow gauge railway.

\section{Acknowledgement}

I am obliged to staff members of UAB Hnit - Baltic, for the valuable information provided by them in their respective fields. I am grateful for their cooperation during the period of my assignment.

\section{References}

[1] ŠMERGELIENĖ, V. - PATACKIENĖ N.: 2004. Paslaugu kokybès vertinimo ypatumai vartotoju požiūriu (Service quality evaluation in terms of consumer). Šiauliai: ŠU. 
[2] ŽILINSKAS, V. - PETRAVIČIENĖ, L.: 2007. Turizmo verslas: plètros konceptualizacija ir tendencijos Lietuvoje (Tourism business: development conceptualization and tendencies in Lithuania). Šiauliai University, Economics and Management, pp. 954-968.

[3] BALEŽENTIS, T. - KRIŠČIUKAITIENĖ, I. - BALEŽENTIS, A. - GARLAND, R.: 2012. Rural tourism development in Lithuania (2003 - 2010) - A quantitative analysis. Tourism Management Perspectives, Volumes 2-3, pp 1-6.

[5] RAMANAUSKIENĖ, J. - GARGASAS, A. - RAMANAUSKAS, J.: 2006. Marketing solutions in rural tourism development in Lithuania. Ekonomika, 74, pp 38-51.

[6] BURINSKIENE, M - RUDZKIENE, V.: 2005. Modeling and forecasting of country tourism development in Lithuania. Journal of environmental engineering and Landscape Management, Vol XIII, No 3, pp. 116-220.

[7] CEYLAN, U. - GÜVEN, O. Z.: 2010. Review: Evaluation of Tourism Management and Ecotourism. Journal of Applied Sciences Research, 6(12), pp. 1943-1952.

[8] STEFANICA, M. - VLAVIAN-GURMEZA, M.: 2010. Ecotourism - model of sustainable tourist development. Studies and Scientific Researches - Economic Edition, 15, pp. 480-486.

[9] Rural Development Programme for Lithuania 2007-2013. Retrieved from: http://www.nma.It/index.php/support/rural-development-programme-2007-2013/685. 